\title{
Women's Empowerment: an Insight into History and the Present Day
}

\author{
Oksana Koshulko \\ Lancaster University M.A. Degree in Economy and Society \\ Ph.D. in Economic Sciences \\ Polissya National University \\ oksanakoshulko2015@gmail.com
}

\section{Abstract}

The article presents the results of research concerning the empowerment of women from the 17th to 21 st century in various countries, including Mexico, the U.K., the U.S.A., Ukraine and France among others. Fourteen cases of women's empowerment in their areas of activity are explored, using case studies collected from primary and secondary data. Twelve of the cases are described and explored using secondary data and two cases using primary data, collected in 2019 in Kyiv, Ukraine. The cases are encrypted as Case $1-C_{-} 1$ through to Case $14-C_{-}$ 14. The article is an important insight into women's empowerment through history to the present, showing how at times women have sacrificed themselves to achieve their aims and how these sacrifices are important for women of today. However, despite the achievements throughout the centuries, women must continue their struggle to obtain full rights and freedom for all women around the world.
Keywords

women's empowerment; history; gender equality

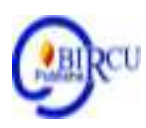

\section{Introduction}

There have always been women in society who tried to make the world better for them and other women by working to bring about changes in their communities and countries.

Women constrained by social and economic circumstances did what they could for women's empowerment within the parameters of their time and situations (Dzholos \& Koshulko, 2021). At times they disrupted traditions, standards of life and customs in their own communities, to obtain a better future, paving the way for following generations of women. Some refused to marry as a protest against traditional customs in their society, some struggled and fought using all available means against the patriarchal world and gender inequality. It is thanks to all these women that the modern understanding of women's empowerment has became clearer and stronger.

Women have always had to prove that they are no worse, and at times are even better, than men in sport, science, art, business, literature, music, military affairs, cinema, etc.

Every small victory for women has contributed to the current large pyramid called women's empowerment. However, full empowerment is still a long way off because many women in the world still struggle to obtain their rights and opportunities. 


\section{Research Method}

The research methodology of the article used primary and secondary sources of information. The primary and secondary data of the research was collected by qualitative methods, such as case studies. The cases have been marked from Case 1 or $C_{-} 1$ to Case 14 or $\mathrm{C}_{-} 14$. Cases from 1 to 12 or from $\mathrm{C}_{-} 1$ to $\mathrm{C}_{-} 12$ were collected and explored using secondary sources of information.

Cases 13 and 14 or C_13 and C_14 were collected using the cases of women in Kyiv, the capital of Ukraine, in 2019 as primary sources of information. The women participating in the case studies were informed about the use of their cases for academic purposes. They all gave their agreement to this use of their cases for academic purposes.

\section{Results and Discussion}

Cases cited in this research explore how women's empowerment developed throughout history in various countries. Women often faced multiple negative factors, restrictions and barriers at the same time but nevertheless, women's empowerment continues to develop.

\subsection{Women's Empowerment as Manifested in Education}

Education is considered to have a very important role in promoting the civilization of a nation. Good quality education can encourage the creation of a quality society, creative and productive until finally able to achieve welfare. Through this national education system, the government should be able to ensure equal distribution of educational opportunities, as well as the relevance and efficiency of education management to face challenges in line with the changing demands of local, national and global life. (Saputra, A. 2018)

Education is the main capital for humans to prosper. The importance of the role of education in improving welfare requires the need for equal distribution of education in each region regardless of socioeconomic, gender and racial backgrounds. In making educational equality, it is important to know the factors that influence educational inequality, namely income inequality, poverty and education gap. (Harahap, E. et al. 2020)

Education has always been one of the most important tools for the development and growth of women's empowerment throughout the world. The problem has often been that patriarchal societies did not allow or encourage the development and growth of women. Fathers and husbands were often more comfortable with humble, unpretentious and illeducated wives and daughters because this facilitates the keeping of women in an inferior position. However, there have always been some women who aspired to study.

\section{a. Case 1}

In the 17th century, a Mexican poet, educator and scholar, C_1, protected the rights of women to be educated. Being very well educated, she understood the importance of education for women and their development and empowerment (Project Vox, 2020). Her ideas were extremely important for both the women of her time and for women of today because she created an example and a basis for women's empowerment through education. Without a doubt, this was one of the first steps to women's empowerment in the 17th century. 


\section{b. Case 2}

A British philosopher, educator, and feminist of the 18th century, C_2, supported the protection of the rights of women in education in her famous essay (A Vindication of the Rights of Woman, 2020). According to the data of Brooklyn Museum, she 'was a renowned women's rights activist who authored A Vindication of the Rights of Woman, 1792, a classic of rationalist feminism that is considered the earliest and most important treatise advocating equality for women. This essay is often seen as the foundation of modern women's rights movements in the Western world' (Brooklyn Museum, 2021). In the essay, she explained why the education of women is so important. In her opinion, a wife should be a companion and friend to a husband, not just the mother of his children. As a mother, she is a major influence on their children and their education and so she needs to be well educated herself. Therefore, this was also one of the first steps on the way to the empowerment of women around the world in the 18th century. Unfortunately, even in the 21 st century, many women in the world do not yet have access to education and personal development. Many women have no opportunity to study, particularly in the poorest and extremist countries of the world (Koshulko, 2020a; Koshulko, 2020b).

\subsection{Manifestations and Examples of Women's Empowerment in Science}

The lives of women who are successful in the field of science are very interesting and important for women's empowerment. These women have contributed to the development of global science and pushed the scientific and technological progress that mankind sees today. These are cases concerning talented women who have made significant contributions to our understanding of science and who have opened the scientific world for other women.

\section{a. Case 3}

A talented Polish scientist, C_3, was a double Nobel Prize winner for her contribution to physics and chemistry. She identified a dangerous element that eventually affected her health and contributed to her early death. However, her contribution to scientific knowledge is significant. Hers was the first case, at the start of the 20th century, of a woman scientist winning the Nobel Prize in physics and chemistry. Later her daughter won the same Prize (Carlton, 2021).

\section{a. Case 4}

A black talented female mathematician, C_4, from the U.S.A., worked in NASA, solving problems, using her skill with extremely complicated mathematics. She helped her country to build spaceships and study the stars during the cold war period of the 60s. While working at NASA she fought against prejudice, racial discrimination, sexism and gender inequality, being forced every time to prove her knowledge and skills. As a result, she overcame all the difficulties, barriers and restrictions with honour and today one of the NASA corps is named after her. Her example has been a shining light for women's empowerment in science throughout the world (NASA, 2020; Carlton, 2021).

\subsection{Manifestations and Examples of Women's Empowerment in Sport}

History shows that many women fought for their right to be part of the international sport community. At the beginning of the 20th century in the Olympic Games women began to be recognized and accepted in some events as sportswomen. However, many women had to fight long and hard to gain the right to represent their country in sport in the 20 th century and this continues in the 21 st century in some areas. 


\section{a. Case 5}

In the second part of the 20th century, a U.S. female professional tennis player C_5 won the match with a male player, the historical match has been called 'Battle of the Sexes'. This match was a historic step in women's tennis, laying the foundations for women's empowerment in this kind of sport in particular, as well as in sport in general. According to the site 'History', '....the tennis player's achievement not only helped legitimize women's professional tennis and female athletes but it was seen as a victory for women's rights in general' (History.com Editors, 2020).

\section{b. Case 6}

In the 21 st century, at the 2020 Olympic Games, a team of German female gymnasts, C_6, decided to wear full-body suits instead of traditional swimsuits, as a demonstration against the sexualisation of women in sport and in particular in gymnastics. This case is a step towards the empowerment of women in sports, to give female gymnasts the right to choose (Pflughoeft, 2021).

\subsection{Manifestations and Examples of Women's Empowerment in Literature}

History has many cases of talented female writers, who could not publish their work under their own names. Some were forced to conceal their female names by using masculine nom de plumes throughout their lives. Some lost their authorship and could not prove it because they were women. However, thanks to the titanic efforts of some, women's empowerment has progressed in this area and female writers have the right to choose.

\section{a. Case 7}

To prove herself as a writer in the 19th century, a French woman, C_7, published her novels under a masculine nom de plume and wore male clothing. She became famous during her writing career but could never reveal her real name. The world knows her as a female writer with a masculine pseudonym (Jasmine, 2017).

\section{b. Case 8}

In the 19th century, a British female writer, C_8, could not publish her novel under her own name and so her novel was published under the name of her husband. Only by titanic efforts and perseverance did she later manage to publish this novel under her real name. Despite suffering from the double standards in literature and society she decided not to use a masculine nom de plume (Sampson, 2018).

\section{c. Case 9}

Another British writer, C_9, at the end of the 18th and the start of the 19th century, decided did not to marry and dedicated her life to creativity. She wrote about the position of women in the daily life of the English middle-class of her time, at a time when women struggled for their own identity and the right to choose (Swallow Prior, 2013).

\subsection{Manifestations and Examples of the Women's Empowerment Development in the System of Justice}

One of the most difficult areas of activity for women in the 20th century was finding a place in the justice system. However, some women achieved their goals and opened doors for the next generations of female lawyers. 


\section{a. Case 10}

A Jewish girl, daughter of Ukrainian immigrants, C_10, decided to be a lawyer in the U.S.A. She was one of the few female students at Harvard Law School at a time when girls were not allowed to study (Oyez, 2020). When she became a lawyer, she dedicated her life to the fight for gender equality and the protection of women in the U.S. and throughout the world. Thanks to her contributions in law, she became one of only two women who served in the U. S. Supreme Court. To achieve gender equality in the U.S., the lawyer helped pass five laws for gender equality, such as (Rodriguez, 2020):

- Employers cannot discriminate against employees based on gender or reproductive choices;

- State-funded schools must admit women;

- Women have the right to financial independence and equal benefits;

- Men are entitled to the same caregiving and Social Security rights as women;

- Juries must include women (Rodriguez, 2020).

Thus, her life and activity created a strong basis for the development of women's empowerment and gender equality in the system of justice.

\section{b. Case 11}

Another American female lawyer, C_11, dedicated her life to protecting political asylum seekers in the U.S.A., especially women. Thanks to her efforts in practical cases, and her wish to change both her country and the world for the better, she assisted the change to the immigration law in her country. These changes mean that every day her work continues the cause of the development of women's empowerment everywhere. She is dedicated to the struggle for justice and gender equality and the protection of political asylum seekers. Thus, her case is an example of political women's empowerment in the U.S.A. and worldwide (Fighting for Justice, Fighting for You, 2020).

\subsection{Manifestations and Examples of Women's Empowerment in Medicine and Military Affairs}

Some women were willing to sacrifice everything to achieve their dreams. Such women are vivid and determined examples of the cause of female empowerment.

\section{a. Case 12}

An Irish woman, C_12, became a military doctor at the start of the 19th century using a man's name. She worked as a man for 50 years hiding her secret under male clothing. Was this because of her passion for the profession of military surgeon, or her determination to get a quality education, at a time when such education was forbidden to women? Either way, it was a huge sacrifice and a giant step towards the empowerment of women in the society of the 19th century (Preez \& Dronfield, 2016; Holland, 2017).

\section{b. Case 13}

Case C_13 was explored using a primary source of information. An unstructured interview was conducted in Kyiv, Ukraine in 2019, with a nurse, C_13, who had become very famous in Ukraine during the Revolution of Dignity in 2014 (Koshulko, 2019). This nurse was injured by a sniper bullet in her neck and only a miracle helped her to survive. She became a symbol of Euromaidan, the symbol of women's steadfastness and spirit during the Revolution. She also demonstrated female strength and endurance at the side of the men in battles during the Revolution in Kyiv, Ukraine, during the winter of 2013-2014. This case helped a lot of women in Ukraine to understand that they too can have the opportunity to change the country and strengthen women's empowerment. 


\section{c. Case 13}

Case C_14 was also explored using a primary source of information. An unstructured interview was conducted in Kyiv, Ukraine, in 2019. The Ukrainian female Major, C_14, fought in the Russian-Ukrainian war, which started in 2014 and continues today. She went to protect the country of Ukraine from the Russian occupiers and also to show that the Ukrainian Army can be a place of gender equality and women's empowerment. The Major fought in the war for several years and returned suffering from post-traumatic stress syndrome. However, thanks to her service and that of similar brave women on the front line, today more and more Ukrainian girls and young women join the Army to serve with contracts or study at the Ukrainian military universities. (Koshulko, 2019; Koshulko, 2021a; Koshulko, 2021b).

\section{Conclusion}

This article presents the results of research on women's empowerment through history in different countries and centuries, from the 17 th to the 21 st century.

Twelve cases have been explored using secondary sources of information and two cases using primary data. These cases are manifestations of women's empowerment in different centuries in various areas of human's activity, such as education, science, sport, literature, the justice system, medicine and military affairs in the U.S.A., U.K., France, Ukraine, Mexico.

The results of the research showed how, over the centuries, women in difficult conditions defended their right to study, to teach, to develop, to be empowered, to write, to practise medicine, to research, to exercise and to publish, so paving the way for future generations of women to exercise their right to self-determination and self-identification in their professions and societies.

The article also teaches how important it is for women to continue to defend their right to self-determination and self-identification even in the 21 st century because women's empowerment needs to progress always and everywhere.

\section{References}

A Vindication of the Rights of Woman. (2020). Online Library of Liberty. Retrieved from https://cutt.ly/DQYZwcS

Brooklyn Museum. (2021). Mary Wollstonecraft. Retrieved from https://cutt.ly/IQ3maho

Carlton, G. (2021). 13 Women Who Made Scientific History. BestColleges.com. Retrieved from https://cutt.ly/bQYvXFE

Dzholos, S., \& Koshulko, O. Women's Empowerment in Action: From Past to Present. MEST Journal. Faculty of Business and Law of the 'MB' University. Vol. 9(2), pp. 15-21, Belgrade, Serbia, 2021. Retrieved from https://cutt.ly/bQUfxa7

Fighting for Justice, Fighting for You. (2020). Law Offices of Judith L. Wood. Retrieved from https://cutt.ly/UQYUns7

Harahap, E. et al. (2020). Determinant Analysis of Education Inequalities in Indonesia. Budapest International Research and Critics Institute-Journal (BIRCI-Journal). P. 1067-1082

History.com Editors. (2020). Billie Jean King triumphs in 'Battle of the Sexes.' History. Retrieved from https://cutt.ly/AQ9akw6

Holland, B. (2017). The Extraordinary Secret Life of Dr. James Barry. History Stories. Retrieved from https://cutt.ly/MQY12fI 
Jasmine, T. (2017). Classic Women Authors in Men's Clothing: Expressing the Masculine. Literary Ladies Guide. Retrieved from https://cutt.ly/gQYd6x4

Koshulko, O. (2019). Women's Roles during War and Occupation in Ukraine since 20132014. Proceedings of the 2019 RSA Central and Eastern Europe Conference 'Metropolises and Peripheries of CEE Countries: New Challenges for EU, National and Regional Policies,' (pp. 32-33), Marie Curie-Skłodowska University, Lublin, Poland, September 11-13.

Koshulko, O. (2020a). Examination of women's access to education and literacy in the framework of empowerment for women around the world. Azure Magazine. European Federation for UNESCO Clubs, Vol. 6, pp. 42-50, Bucharest, Romania.

Koshulko, O. (2020b). Examination of Women's Empowerment in Some Post-Soviet Countries. Proceedings of the Three-Day International Virtual Conference on Gender Studies, Cape Comorin Publisher, (pp. 53-54), Kanyakumari, Tamilnadu, India, September 16-18.

Koshulko, O. (2021a). Gender Equality as a Sustainable Development Goal for Ukraine. Proceedings of the 2nd International Scientific and Practical Conference on Mechanisms for Sustainable Economic Development: Problems, Prospects, International Experience. Kharkiv State University of Food Technology and Trade, Kharkiv, Ukraine, (pp. 198-199), April 23.

Koshulko, O. (2021b). Women's Political Empowerment in Poland and Ukraine: Present and Future. Proceedings of the 1st International Conference on Migration and Gender Issues (COMAGI 2021), Transnational Press London, London, U.K., (pp. 83-84), March 11-12.

NASA. (2020). Mary W. Jackson Biography. Retrieved from https://cutt.ly/6n3mrBR

Oyez. (2020). Ruth Bader Ginsburg. Retrieved from https://cutt.ly/cn3mgVY

Pflughoeft, A. (2021). German gymnasts wore unitards to protest the 'sexualization' of their sport. Deseret News Publishing Company. Retrieved from https://cutt.ly/6QYdsZC

Preez, M. \& Dronfield, J. (2016). Dr James Barry: The Irish woman who fooled the British Empire. Retrieved from https://cutt.ly/pn3nJaQ

Project Vox. (2020). Sor Juana (1648-1695). Retrieved from https://cutt.ly/6n3nZTC

Rodriguez, L. (2020). 5 Laws Ruth Bader Ginsburg Championed to Support Gender Equality. Retrieved from https://cutt.ly/KQ30Pks

Sampson, F. (2018). Frankenstein at 200 - why hasn't Mary Shelley been given the respect she deserves? Guardian News. Retrieved from https://cutt.ly/yQYhqQk

Saputra, A. (2018). Allocation of Education Budget in Indonesia. Budapest International Research and Critics Institute-Journal (BIRCI-Journal). P. 142-148.

Swallow Prior, K. (2013). I Learned Everything I Needed to Know About Marriage From Pride and Prejudice. The Atlantic. Retrieved from https://cutt.ly/1QYhFUg 